\title{
Upgrading the Northern Coast Residential Building Performance by using Affordable Methods (Marsa Matrouh Case of Study)
}

\author{
Tamer Elgohary, Nisreen Abdeen
}

\begin{abstract}
Residential buildings at coastal zone of Egypt face a great shortage in ventilation and thermal comfort, although it has a good orientation to the north. The research focused on Marsa Matrouh city because it is a poor community that has the privilege of sea view. So the research goal is to apply passive natural techniques to apply thermal comfort in this region to decrease the high rise temperature, the IPCC reports stated that there will be high rise temperature for this region as a results of climate change scenarios, for this reason the research aimed to upgrade the existed residential building to cope with this expected high temperature in natural passive way, also it is a good sample for implementing national architecture identity to achieve sustainability by using wooden shatter, wind capture and double glazing. In this research we proved that the optimum affordable natural ventilation technique is the using of double glassing and wooden overhang above each window, this suggested system allowed the air flow to be sucked in order to reduce internal temperature and energy consumption inside any residential buildings. Also the research verified the efficiency of this system by using soft computing technique (Design builder) for measuring the quantities of air flow, solar energy, carbon dioxide emissions, temperature and energy consumption. We aimed to optimize the suggested system to create a new methodology for thermal comfort at coastal zones to solve the high rise temperature issue.
\end{abstract}

Keywords Coastal zone, thermal comfort; natural ventilation, low cost building; wind capture; Mars Matrouh

\section{INTRODUCTION}

Through the recent years climate change became a very important challenge for architecture engineers to overcome its negative effects on buildings which include the rising of air temperature, this will decrease the thermal comfort for building residents and will increase energy consumption as a result of using mechanical ventilation and air conditioner (AC), also the operation of this devices will increase greenhouse gases in form of $\mathrm{CO}_{2}$ emissions that is responsible for global warming and climate change, for all that buildings performance must be upgraded to cope with climate change scenarios and solar radiation flocculation (Iskander, 2013) ${ }^{[1]}$. Climate change scenarios will mainly affect negatively on coastal zone and on existing residential buildings thermal comfort

Revised Manuscript Received on December 25, 2020.

* Correspondence Author

Tamer Elgohary*, Civil department, Heliopolis university, Cairo, Egypt. Email: tamer.elgohary@hu.edu.eg

Nisreen Abdeen, Architecture department, Heliopolis universityy, Cairo, Egypt. Email: Nisreen Abdeen@hu.edu.eg

(C) The Authors. Published by Blue Eyes Intelligence Engineering and Sciences Publication (BEIESP). This is an open access article under the CC BY-NC-ND license (http://creativecommons.org/licenses/by-nc-nd/4.0/)

\section{A. Coastal zone management:}

Coastal zone management is the operation processes of coastal zone resources to achieve sustainable development goals and to protect the surrounding environment, also coastal management is aiming to find solutions for coastal problems in order to maximize the benefits of existing resources, this will include the upgrading of buildings performance in the coastal urban areas by using affordable methods, that will provide both visual and thermal comfort with minimum energy consumption. The paper focused on strengthen the problems as an opportunity for upgrading building performance, coping with climate change must include the climate change scenarios threats and reliable assessment methodology for new urban planning in this region to fulfil environmental and social goals (World Bank, 1996) ${ }^{[2]}$.

B. Coastal zone management issues in Egypt related to urban areas:

1- Land stress due to the overpopulation in coastal zone.

2-Optimizing building performance in near urban areas to achieve thermal and visual comfort.

3-The pollution of the surrounding environment Climate change effect that lead us to decrease energy consumption and $\mathrm{CO}_{2}$ emissions.

\section{Egypt future climate change scenarios (IPCC)}

The future climate change scenarios in Egypt according to IPCC report:

1-Temperature rise will vary from 3.1 to $4.7^{\circ} \mathrm{C}$ by 2060 (USAID, 2015) ${ }^{[3]}$..

2-Rain precipitation will be decreased by $10 \%$ to $40 \%$.

3-The sea level rise will be of average value of $50 \mathrm{~cm}$ at year 2050 to $1 \mathrm{~m}$ at year 2100 .

Based on USAID fact sheet 2015 (USAID, 2015) ${ }^{[3]}$. the climate change future scenarios will be as follow:

1-Scenario (1) for the year period (2020-2049) assumed that the rain annual precipitation will be changed by $0,1 \mathrm{~mm} /$ day, Also the high rise of atmosphere temperature will increase the evaporation processes and that will expose Egypt to drought, Mediterranean Sea level rise will be between low $(0.07 \mathrm{~m})$, medium $(0.11 \mathrm{~m})$, and high $(0.25 \mathrm{~m})$ (El-Nahry \& Doluschitz, 2009) ${ }^{[4]}$. 2-Scenario (2) for the year period (2040-2059) assumed that the rain annual precipitation will be low, Also the high rise of atmosphere temperature will increase the evaporation processes and that will expose Egypt, Mediterranean Sea level rise will be between low $(0.11 \mathrm{~m})$, medium $(0.20 \mathrm{~m})$,

\section{Published By:}

Blue Eyes Intelligence Engineering and Sciences Publication

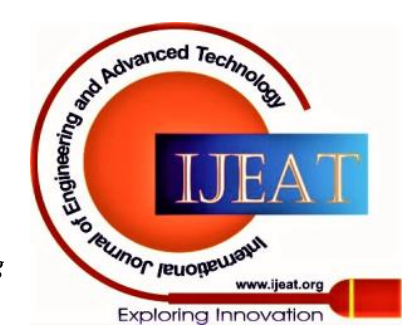




\section{Upgrading the Northern Coast Residential Building Performance by using Affordable Methods (Marsa Matrouh Case of Study)}

and high $(0.40 \mathrm{~m})$ according to (El-Nahry \& Doluschitz, 2009) $)^{[4]}$.

\section{Thermal comfort}

The temperature plays an important role in providing thermal comfort, as the temperature difference is related to the proportional of heat transfer and relative humidity as shown in figure 1 , indicating the heat to the environment. So, the paper is focusing on measuring the heat loss and again in the environment, in summer and in winter, to see the human impact on the place, as human body release an excess heat in summer, and loses heat in winter. The reason for using HVAC (air conditioning, heating and ventilation) is to maintain thermal comfort inside enclosures.

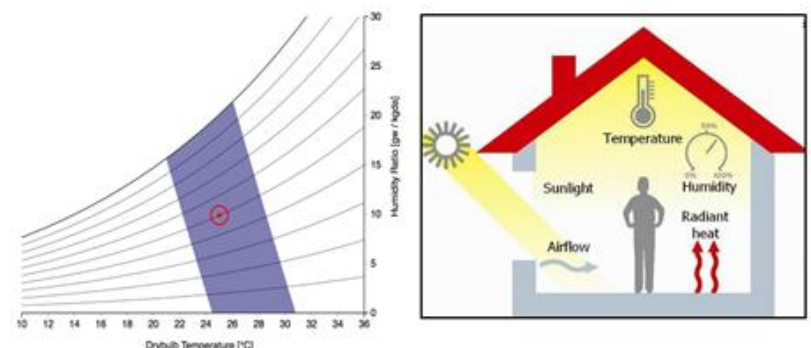

Figure 1. Temperature versus humidity ( Wikipedia ${ }^{[5]}$ \& Mamdooh, 2016 $^{[6]}$.)

Relative humidity causing discomfort especially in the hot climate, it increases the skin sensation for temperature, so in order to achieve any thermal comfort inside any building we have first to remove humidity from room voids before cooling the internal air.

\section{E. The study location (Marsa Matrouh)}

Marsa Matruh is very important city in the Egyptian northern costal line along the Mediterranean sea, also it is an important port and the capital of Matrouh Governorate. It is located at the west of Alexandria, almost $240 \mathrm{~km}$ from the Nile delta, the city considered to be a very important touristic place and containing $l$ urban area full with modern and traditional buildings, it is also at the north of Egyptian eastern desert that has an arid climate (Wikepedia) ${ }^{[7],[8]}$.

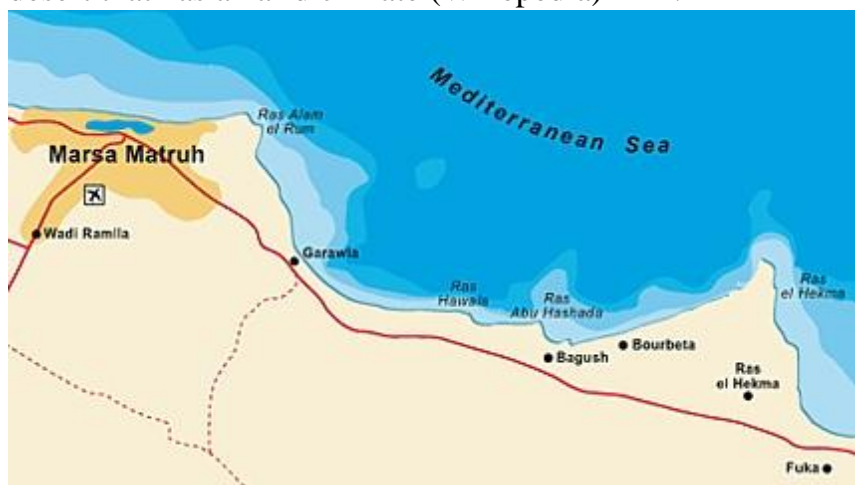

Fig. 2 Marsa Matrouh map (egyptbesttrip.com)

Although the dominating climate at Marsa Matrouh is the arid climate there is air winds from the Mediterranean Sea side, this northern prevailing wing and sea breeze cooling the air atmosphere at the city urban area especially for the building of main frontage toward the north, while the building of southern frontage suffer from high air temperature and the lack of natural ventilation, so these buildings need to be upgraded in order to increase its performance by affordable solutions, tis solutions will focus on decreasing the internal temperature of the buildings and to create air flow of high velocity by using passive ventilations, the air flow will cause air temperature to be decreased to produce thermal comfort for buildings residents, hot humid air increase the energy consumption of any building as a result of using air conditioner (AC), so the main idea to choose such area is to decrease the energy consumption for the building by using natural ventilation instead of mechanical none.

Marsa Matrouh population is 573,427 capita and its area is almost $166,563 \mathrm{Km} 2$, also the city has long cost line with white sand that cause more reflection of sun radiation to cause more heat. The city is dominated by a Mediterranean coastal climate, its weather is mild in summer and cold in winter, May and September are ideal months for visiting the city, the temperature of Marsa Matruh reaches more than 28 degrees Celsius in summer and less than 13 degrees Celsius in winter

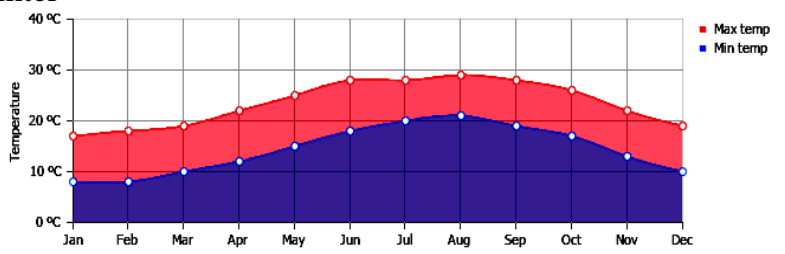

Fig. 3. Thermal map for MArsa Matrouh (weather-and-climate.com) $^{[9]}$

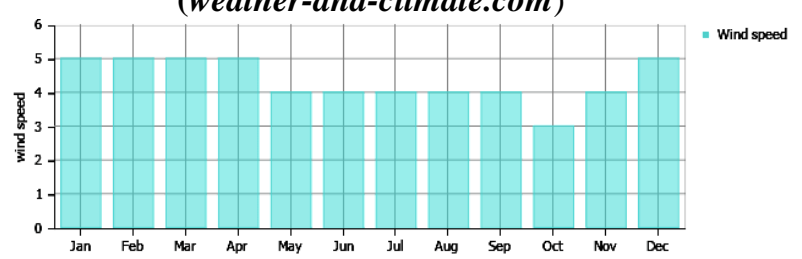

Fig.4. Wind speed map for MArsa Matrouh (weather-and-climate.com) ${ }^{[9]}$

Table-I: The temperature range for the western northern coastal zone of Egypt (Wikepedia) ${ }^{[10]}$.

\begin{tabular}{|c|c|c|c|c|c|}
\hline Month & $\begin{array}{c}\text { Record } \\
\text { high } \\
{ }^{\circ} \mathbf{C ~}\left({ }^{\circ} \mathbf{F}\right)\end{array}$ & $\begin{array}{c}\text { Average } \\
\text { high }{ }^{\circ} \mathbf{C} \\
\left({ }^{\circ} \mathbf{F}\right)\end{array}$ & $\begin{array}{c}\text { Daily } \\
\text { mean } \\
{ }^{\circ} \mathbf{C ~}\left({ }^{\circ} \mathbf{F}\right)\end{array}$ & $\begin{array}{c}\text { Average } \\
\text { low } \\
{ }^{\circ} \mathbf{C} \\
\left({ }^{\circ} \mathbf{F}\right)\end{array}$ & $\begin{array}{c}\text { Record } \\
\text { low } \\
\left({ }^{\circ} \mathbf{C}\right.\end{array}$ \\
\hline Jan & 31 & 18.9 & 14 & 9 & 1.2 \\
\hline Feb & 34.2 & 20.4 & 15.1 & 9.7 & 3.6 \\
\hline Mar & 37.9 & 23.5 & 17.6 & 11.6 & 5 \\
\hline Apr & 43.2 & 28.3 & 21.5 & 14.6 & 7.6 \\
\hline May & 47.8 & 32 & 24.9 & 17.7 & 12.3 \\
\hline Jun & 46.4 & 33.9 & 27 & 20.1 & 16 \\
\hline Jul & 42.6 & 34.7 & 28.4 & 22 & 18.2 \\
\hline Aug & 43.4 & 34.2 & 28.2 & 22.1 & 19 \\
\hline Sep & 43.7 & 32.6 & 26.6 & 20.5 & 14.5 \\
\hline Oct & 41 & 29.2 & 23.3 & 17.4 & 12.3 \\
\hline Nov & 37.4 & 24.8 & 19.5 & 14.1 & 5.2 \\
\hline Dec & 30.2 & 20.3 & 15.4 & 10.4 & 3 \\
\hline
\end{tabular}

\section{F. Shading using Passive solar energy:}

Among all the cooling techniques, passive solar shading plays a great role in the buildings thermal cooling, relevant to the cost effectiveness. Egypt faces a great rise in temperature out of masonry houses, causing a great consumption in electricity. Where the indoor temperature reaches to $41 \mathrm{c}$. So, the research aims to upgrade the building performance by using available materials.,

Published By:

Blue Eyes Intelligence Engineering and Sciences Publication

(C) Convriaht: All riahts reserved.

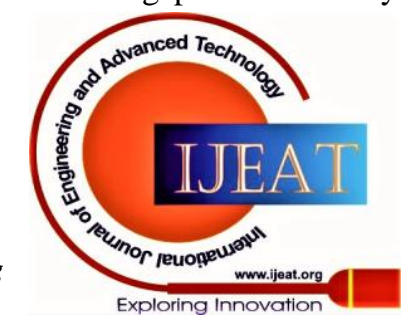


like wooden shutters, shed, as it reduces the temperature near outer wall by 2 c to 2.5 c.

These techniques help to reduce the ambient indoor temperature, as it is needed, such as solar shading air exchange rate and, building insulation, where the decrease is up to $4.4 \mathrm{c}$ to $6.8 \mathrm{c}$ in the room temperature, that helps to maintain its temperature. Development of solar shading is more effective rather than conventional building without shade. The researches applied different environmental scenarios such as overhangs, louvers and awnings, using computing simulation by design builder, to assess the best environmental impact factor. Either these alternatives are placed separately from building façade. The paper aim to apply an effective framework for designing low Cost Sustainable Residential Building using Passive Solar energy. It depends mainly upon the building orientation. So, the shading textured walls is an effective insulator, as it increases the shading area as well as, it provides Highly portion of their surface in shade to be cool, and helps it to cool down at night faster (Kamal, 2012) ${ }^{[11]}$., (Batt et al, 1991) ${ }^{[12]}$., (Kumar et al, 2005) ${ }^{[13]}$.

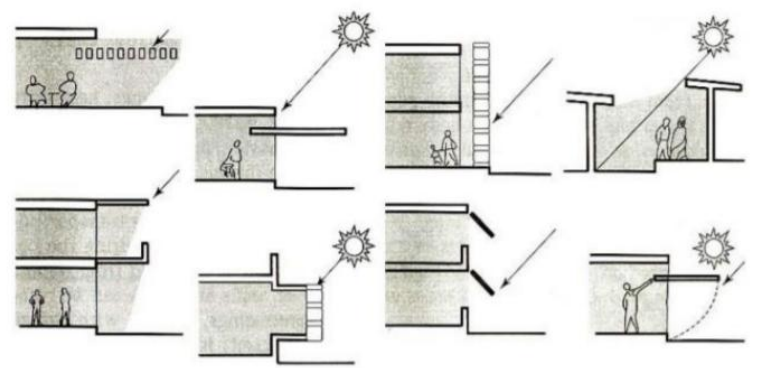

Fig. 5. Different types of shading devices (Kamal, 2012) ${ }^{[11]}$

\section{G. The insulation value on the building envelope:}

It plays a great role in reducing the heat gain and heat loss, as it decreases the heat transfer in or out of the building.it is too effective in isolating interior surfaces from the external conditions, shown in interior mean radiant temperature (MRT), and reduces draughts as well .So the paper measures the impact of insulator between wall and air, and shows the difference in measurement by different seniors to reduce the space-conditioning load .

So, the thermal mass of external walls in hot climate, should have good insulator, placed in a right location, with optimum thickness, to be weakly coupled with external impact and strongly coupled in the internal subdivision walls.

To reduce the solar heat, gain factor, is by using air capture walls, as it helps in the heat transfer through air by convection and radiation to reduce space-conditioning loads (Rajendran, \& Jena, 2014) ${ }^{[14]}$.

\section{CASE OF STUDY}

\section{A. Building description}

We have chosen a residential building at coastal zone of Marsa matrouh city as shown in figure 6, the building consists of three floors that contributes area of almost $400 \mathrm{~m}^{2}$ for each floor, also the building has frontage that facing the south direction while its backyard facing the north direction, the total height of the building is $11 \mathrm{~m}$ as shown in figure 7.

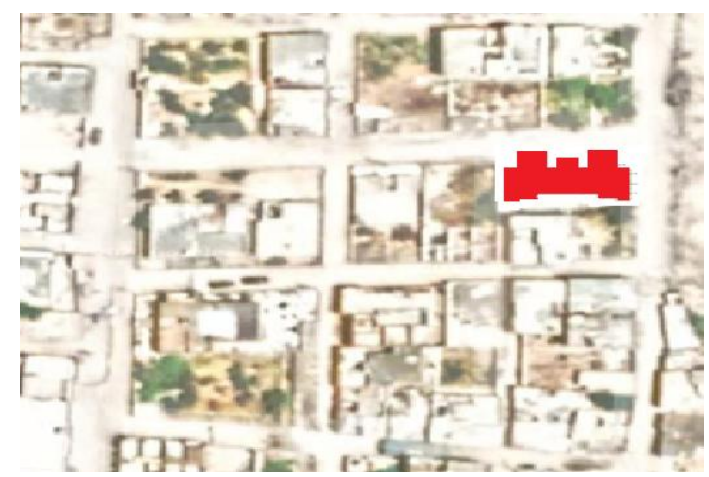

Fig.6. Building google map

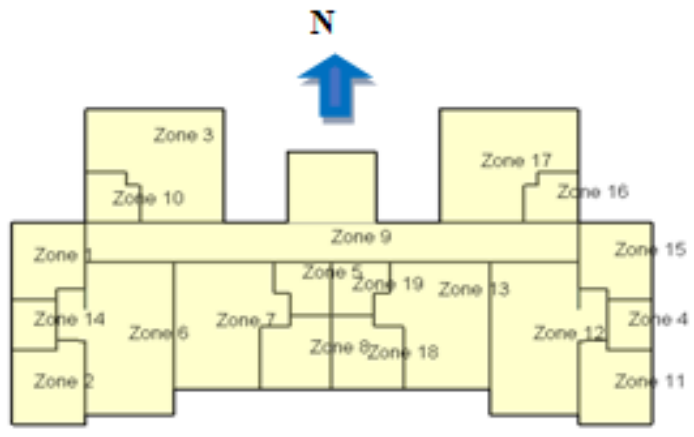

Fig.7. Building plan

\section{B. Environmental performance buildings scenarios:}

The case study is assessed by applying simulation through seven different environmental scenarios, to assess the most effective impact of the building performance, in this region. These scenarios included the original case with its existed circumstances having the balcony eliminated to gain more area in the internal space. The first case we used double glassing in the southern façade, while in the second case we used wooden shading devices above each window, in the third case we used both double glassing and wooden overhang above each window, the fourth case is like the third case except that we used wooden from for the double glassing. However, in the fifth case we used wooden external wind capture of $10 \%$ transmittance at the northern frontage. While in the sixth case we used wooden external wind capture of $50 \%$ transmittance at the northern frontage, all that can be shown in figures $8,9.10$ and 11 . The researches done all that to assess the best scenario, to be applied as a methodology for new buildings in this region in order to let the sustainability as a local zone identity as shown in figure 12 . From our case study we focused on energy consumption and internal temperature as an assessment tools for building performance, to find the optimum alternative by using the energy simulation tools (Design builder and CFD software) as an application for the new buildings, shown in the quantitative model to fill the gap between the existing conventional buildings and the new one. The model enhances the decision making for choosing the ideal building performance design coping with our nation target.

Published By:

Blue Eyes Intelligence Engineering and Sciences Publication

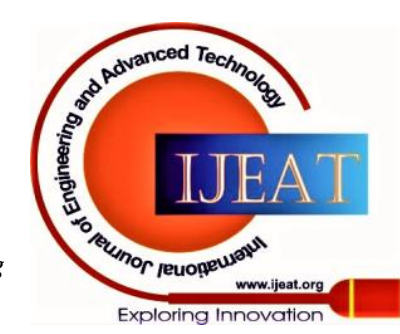


Upgrading the Northern Coast Residential Building Performance by using Affordable Methods (Marsa Matrouh Case of Study)

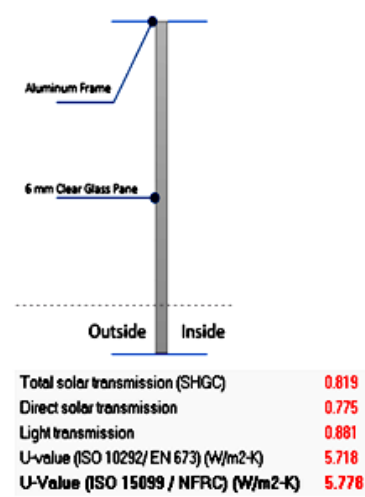

Fig.8. Single and double glassing cross section

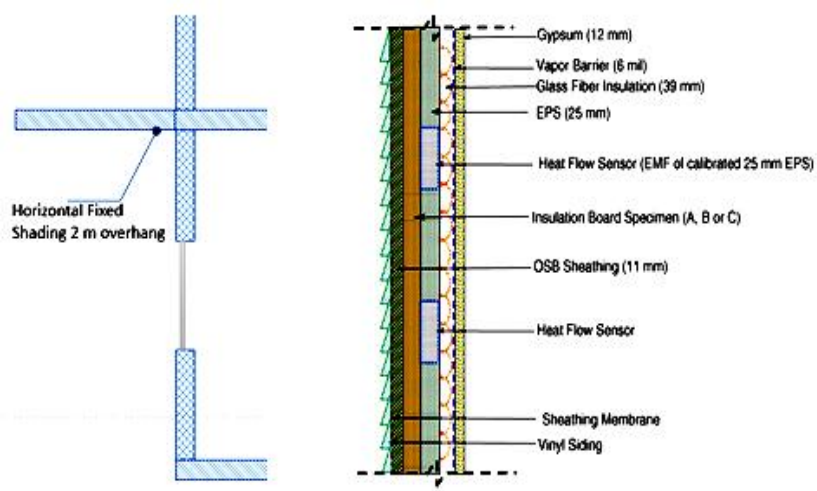

Fig. 9. Wooden over hang and wind capture wall cross section
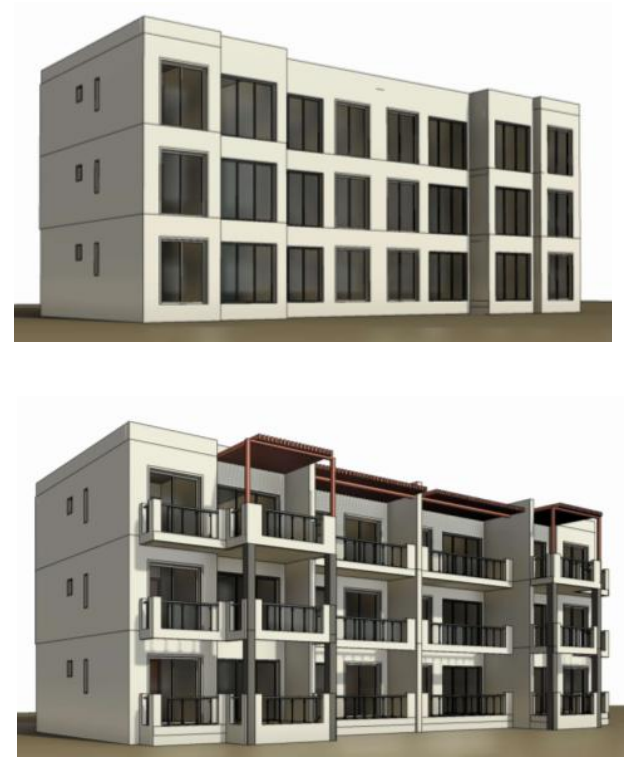

Fig. 10. Cases 1,2.3 and 4

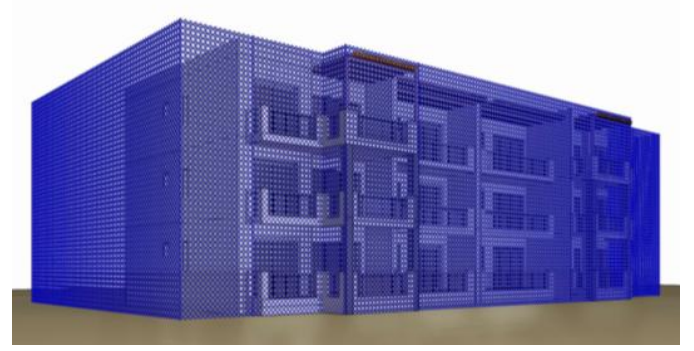

Fig. 11. Cases 5 and 6

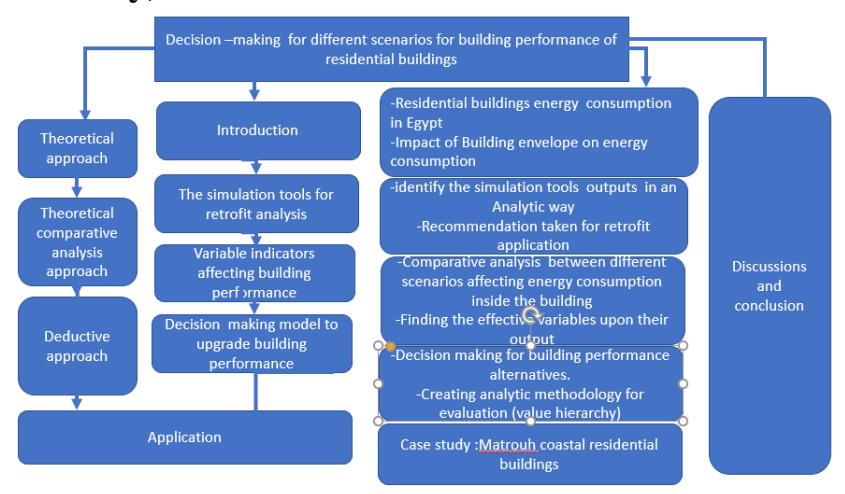

Fig. 12. Research methodology

\section{RESULTS}

The results that were yielded from design builder for energy consumption and internal temperature for all cases are mentioned in table II, III, IV and V for 10 days as an example and all the total energy data were shown from figure 12 to figure 15. Also the results that were yielded from CFD software for air flow of base case, case 2 and case 5 are shown from figure 16 to figure 20 .

Table-II: Design builder software analyses for the base

\begin{tabular}{|c|c|c|c|c|c|c|c|c|c|}
\hline \multicolumn{10}{|c|}{$11 / 8$ to $20 / 8$} \\
\hline Case & Date & $\overbrace{\infty}^{\infty}$ & $\underset{\infty}{\mathbb{J}}$ & $\stackrel{2}{\infty}$ & $\underset{\infty}{\stackrel{0}{L}}$ & $\underset{\infty}{\leftarrow}$ & $\stackrel{\infty}{\infty}$ & 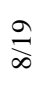 & $\underset{\infty}{\infty}$ \\
\hline \multirow{5}{*}{ 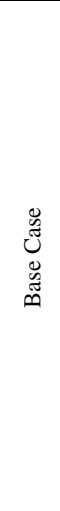 } & $\begin{array}{l}\text { Room } \\
\text { Electricity } \\
\text { (kWh) }\end{array}$ & $\stackrel{2}{\circ}$ & 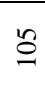 & $\stackrel{\leftrightarrow}{\circ}$ & 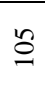 & 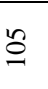 & 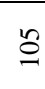 & 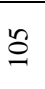 & $\stackrel{\leftrightarrow}{\circ}$ \\
\hline & $\begin{array}{c}\text { Lighting } \\
(\mathrm{kWh})\end{array}$ & $\begin{array}{l}\sigma \\
\dot{\omega}\end{array}$ & فे & ब्षे. & 足 & $\stackrel{\text { In }}{\stackrel{i}{N}}$ & $\stackrel{\text { I্ }}{\stackrel{\sim}{\sim}}$ & $\stackrel{m}{\sim}$ & $\stackrel{2}{i}$ \\
\hline & $\begin{array}{l}\text { Cooling } \\
\text { (Electricity) } \\
\text { (kWh) }\end{array}$ & $\tilde{N}$ & สิ & बे & $\stackrel{2}{2}$ & $\stackrel{0}{\circ}$ & $\stackrel{0}{\circ}$ & $\stackrel{O}{N}$ & $\vec{\sim}$ \\
\hline & $\begin{array}{c}\text { Air } \\
\text { Temperature } \\
\left({ }^{\circ} \mathrm{C}\right)\end{array}$ & 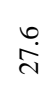 & $\begin{array}{l}\stackrel{0}{\mathbf{N}} \\
\text { in }\end{array}$ & $\stackrel{+}{\stackrel{\sim}{~}}$ & $\stackrel{m}{\sim}$ & $\vec{m}$ & 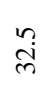 & ma & 27 \\
\hline & $\begin{array}{l}\text { Total Energy } \\
\text { Consumption } \\
\text { (kWh) }\end{array}$ & 总 & 志 & సे & 今े & స్తి & సิ & $\stackrel{\infty}{m}$ & $\begin{array}{c}34 \\
9\end{array}$ \\
\hline
\end{tabular}

Table-III: Design builder software analyses for case 1 from 11/8 to 20/8

\begin{tabular}{|c|c|c|c|c|c|c|c|c|c|}
\hline Case & Item & $\stackrel{\infty}{\infty}_{\infty}^{m}$ & $\underset{\infty}{\frac{\pi}{L}}$ & $\stackrel{2}{\stackrel{\infty}{\infty}}$ & $\underset{\infty}{\stackrel{\infty}{L}}$ & $\underset{\infty}{\overline{1}}$ & 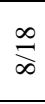 & $\underset{\infty}{\overparen{D}}$ & 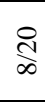 \\
\hline \multirow{5}{*}{ 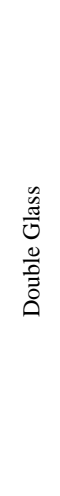 } & $\begin{array}{l}\text { Room } \\
\text { Electricity } \\
(\mathrm{kWh})\end{array}$ & 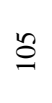 & 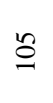 & 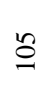 & 号 & $\stackrel{\leftrightarrow}{\circ}$ & $\stackrel{9}{9}$ & 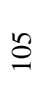 & 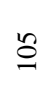 \\
\hline & $\begin{array}{c}\text { Lighting } \\
(\mathrm{kWh})\end{array}$ & $\begin{array}{l}\tilde{H} \\
\vec{m}\end{array}$ & $\stackrel{\circ}{\dot{m}}$ & $\stackrel{\text { ले }}{m}$ & fै & ते & m & & $\overrightarrow{\bar{m}}$ \\
\hline & $\begin{array}{l}\text { Cooling } \\
\text { (Electricity) } \\
(\mathrm{kWh})\end{array}$ & d্ & 骂 & $\stackrel{\infty}{\rightarrow}$ & में & $\stackrel{0}{\circ}$ & $\stackrel{0}{0}$ & 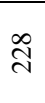 & $\stackrel{\sim}{\circ}$ \\
\hline & $\begin{array}{c}\text { Air } \\
\text { Temperature } \\
\left({ }^{\circ} \mathrm{C}\right)\end{array}$ & $\stackrel{n ?}{\stackrel{n}{\sim}}$ & $\stackrel{\text { Ln }}{\underset{N}{N}}$ & 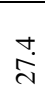 & $\stackrel{m}{\stackrel{n}{\sim}}$ & $\begin{array}{l}\infty \\
\stackrel{m}{0} \\
\dot{m}\end{array}$ & $\overrightarrow{\text { mi }}$ & $\overrightarrow{\text { d. }}$ & $\stackrel{\text { ?ִ }}{\stackrel{\sim}{\sim}}$ \\
\hline & $\begin{array}{l}\text { Total Energy } \\
\text { Consumption } \\
\text { (kWh) }\end{array}$ & 离 & $\vec{m}$ & $\stackrel{0}{m}$ & Dे & 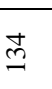 & $\stackrel{M}{\rightarrow}$ & 岂 & ले \\
\hline
\end{tabular}

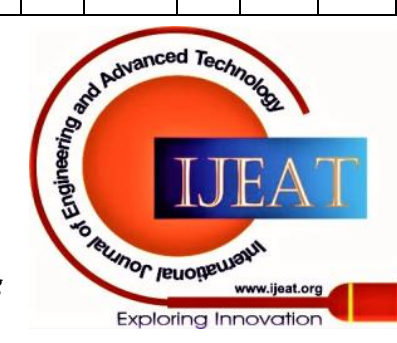


Table-IV: Design builder software analyses for case 2,3 and 4 from $11 / 8$ to $20 / 8$

\begin{tabular}{|c|c|c|c|c|c|c|c|c|c|}
\hline Case & Date & $\stackrel{\infty}{\infty}_{\infty}^{\infty}$ & $\frac{d}{\infty}$ & $\stackrel{\llcorner}{\stackrel{2}{\infty}}$ & $\stackrel{0}{\infty}$ & $\stackrel{\hat{\infty}}{\infty}$ & $\stackrel{\infty}{\infty}$ & $\stackrel{9}{\infty}$ & 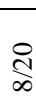 \\
\hline \multirow{5}{*}{ 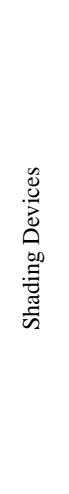 } & $\begin{array}{l}\text { Room } \\
\text { Electricity } \\
(\mathrm{kWh})\end{array}$ & 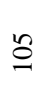 & 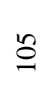 & 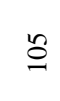 & 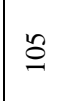 & $\stackrel{2}{\circ}$ & 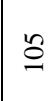 & 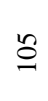 & 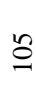 \\
\hline & $\begin{array}{l}\text { Lighting } \\
\text { (kWh) }\end{array}$ & 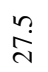 & $\stackrel{+}{\stackrel{\sim}{~}}$ & 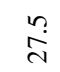 & Nִ & ᄅ्் & 롬 & 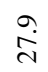 & $\stackrel{m}{\stackrel{N}{N}}$ \\
\hline & $\begin{array}{l}\text { Cooling } \\
\text { (Electricity) } \\
(\mathrm{kWh})\end{array}$ & के & ஓं & 今 & 苟 & $\stackrel{0}{\circ}$ & $\stackrel{\circ}{0}$ & $\dot{\mathbb{N}}$ & $\stackrel{\Re}{\sigma}$ \\
\hline & $\begin{array}{c}\text { Air } \\
\text { Temperature } \\
\left({ }^{\circ} \mathrm{C}\right)\end{array}$ & 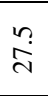 & $\stackrel{\text { ำ }}{\stackrel{N}{N}}$ & 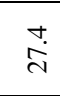 & $\stackrel{m}{\stackrel{n}{N}}$ & $\hat{\dot{m}}$ & $\frac{9}{m}$ & $\stackrel{\infty}{\sim}$ & $\stackrel{\text { ำ }}{\stackrel{\sim}{N}}$ \\
\hline & $\begin{array}{c}\text { Total Energy } \\
\text { Consumption } \\
(\mathrm{kWh})\end{array}$ & $\begin{array}{l}\text { Ḷ } \\
\text { ते } \\
\text { ஸे }\end{array}$ & $\begin{array}{l}\stackrel{\infty}{\mathrm{I}} \\
\text { }\end{array}$ & $\begin{array}{l}\stackrel{0}{0} \\
\dot{m}\end{array}$ & $\begin{array}{l}\infty \\
\infty \\
\infty \\
\sim \\
\sim\end{array}$ & $\begin{array}{l}\text { Na } \\
\stackrel{0}{-}\end{array}$ & $\stackrel{\circ}{\stackrel{\oplus}{\oplus}}$ & ํ. & $\begin{array}{l}\overrightarrow{\dot{\omega}} \\
\text { ஸे }\end{array}$ \\
\hline \multirow{5}{*}{ 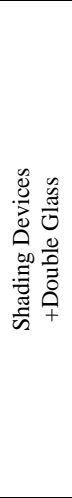 } & $\begin{array}{l}\text { Room } \\
\text { Electricity } \\
(\mathrm{kWh})\end{array}$ & $\stackrel{\leftrightarrow}{\varrho}$ & 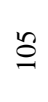 & 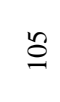 & $\stackrel{\llcorner}{\varrho}$ & $\stackrel{\stackrel{ }{O}}{\sim}$ & 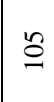 & 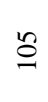 & 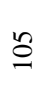 \\
\hline & $\begin{array}{l}\text { Lighting } \\
\text { (kWh) }\end{array}$ & $\begin{array}{l}0 \\
\text { } \\
\text { m. }\end{array}$ & ঙ̀ं & $\stackrel{\llcorner}{\mathrm{i}}$ & $\overrightarrow{\dot{p}}$ & $\stackrel{\infty}{\stackrel{\rho}{\dot{m}}}$ & बें & $\stackrel{\vec{m}}{\ddot{m}}$ & $\stackrel{\text { }}{\text { mे }}$ \\
\hline & $\begin{array}{l}\text { Cooling } \\
\text { (Electricity) } \\
(\mathrm{kWh})\end{array}$ & $\hat{\curvearrowright}$ & $\begin{array}{l}m \\
\stackrel{m}{\infty} \\
\infty \\
-1\end{array}$ & స̃. & 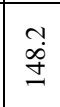 & $\stackrel{\circ}{\circ}$ & $\stackrel{0}{0}$ & $\begin{array}{l}\stackrel{a}{2} \\
\stackrel{n}{N}\end{array}$ & $\begin{array}{l}-1 \\
\dot{0} \\
\sim\end{array}$ \\
\hline & $\begin{array}{c}\text { Air } \\
\text { Temperature } \\
\left({ }^{\circ} \mathrm{C}\right)\end{array}$ & $\stackrel{\text { ำ }}{\text { N }}$ & $\stackrel{\text { กุ }}{\text { ล }}$ & $\stackrel{+}{\stackrel{\sim}{N}}$ & $\stackrel{m}{\stackrel{n}{*}}$ & $\stackrel{\varphi}{\dot{m}}$ & $\stackrel{\infty}{m}$ & $\stackrel{\circ}{\stackrel{\infty}{N}}$ & 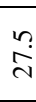 \\
\hline & $\begin{array}{c}\text { Total Energy } \\
\text { Consumption } \\
(\mathrm{kWh})\end{array}$ & సે & $\frac{\sigma}{m}$ & $\underset{ల}{~}$ & $\stackrel{\mathscr{D}}{\text { N }}$ & 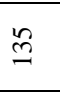 & 节 & 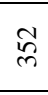 & $\underset{\widetilde{m}}{\tilde{m}}$ \\
\hline \multirow{5}{*}{ 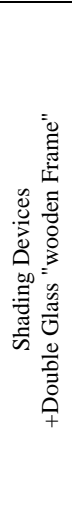 } & $\begin{array}{c}\text { Room } \\
\text { Electricity } \\
(\mathrm{kWh})\end{array}$ & 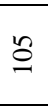 & 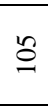 & 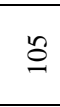 & 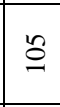 & 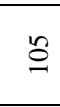 & $\stackrel{ }{\circ}$ & 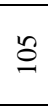 & 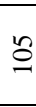 \\
\hline & $\begin{array}{l}\text { Lighting } \\
(\mathrm{kWh})\end{array}$ & $\begin{array}{l}0 \\
\stackrel{\sim}{\text { m }}\end{array}$ & 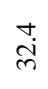 & $\stackrel{\llcorner}{\stackrel{n}{n}}$ & Nै & $\stackrel{\infty}{\stackrel{\infty}{\infty}}$ & ஜे & $\ddot{m}$ & $\stackrel{m}{\sim}$ \\
\hline & $\begin{array}{l}\text { Cooling } \\
\text { (Electricity) } \\
\text { (kWh) }\end{array}$ & $\stackrel{\infty}{\infty}$ & $\underset{\sim}{\infty}$ & $\stackrel{\dot{\theta}}{0}$ & $\stackrel{\infty}{\underset{J}{J}}$ & $\stackrel{\circ}{\circ}$ & $\stackrel{\circ}{\circ}$ & $\stackrel{\Delta}{\sim}$ & $\stackrel{\mathscr{\sim}}{\stackrel{\sim}{\sim}}$ \\
\hline & $\begin{array}{c}\text { Air } \\
\text { Temperature } \\
\left({ }^{\circ} \mathrm{C}\right)\end{array}$ & $\stackrel{\text { ำ }}{\text { N }}$ & $\stackrel{\text { ำ }}{\stackrel{N}{N}}$ & 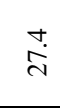 & $\stackrel{m}{\stackrel{n}{N}}$ & $\ddot{\dot{m}}$ & $\stackrel{\infty}{\dot{m}}$ & $\stackrel{0}{\infty}$ & $\stackrel{\stackrel{2}{\curvearrowright}}{\sim}$ \\
\hline & $\begin{array}{l}\text { Total Energy } \\
\text { Consumption } \\
(\mathrm{kWh})\end{array}$ & సิ & $\stackrel{\vec{m}}{ }$ & ஜे & 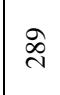 & $\stackrel{\stackrel{m}{m}}{\rightarrow}$ & $\stackrel{\dot{m}}{\rightarrow}$ & ผึ่ & $\tilde{\sim}$ \\
\hline
\end{tabular}

Table-V: Design builder software analyses for case 5 and 6 from 11/8 to 20/8

\begin{tabular}{|c|c|c|c|c|c|c|c|c|c|}
\hline Case & Date & $\stackrel{m}{\infty}$ & $\stackrel{\infty}{\infty}^{+}$ & $\sum_{\infty}^{\infty}$ & $\stackrel{\infty}{\infty}_{\infty}^{0}$ & $\stackrel{\curvearrowright}{\infty}$ & $\sum_{\infty}^{\infty}$ & $\stackrel{\infty}{\infty}$ & 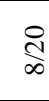 \\
\hline \multirow{5}{*}{ 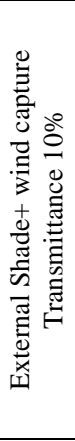 } & $\begin{array}{c}\text { Room } \\
\text { Electricity } \\
(\mathrm{kWh})\end{array}$ & 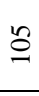 & 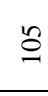 & 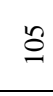 & 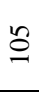 & $\stackrel{2}{\circ}$ & 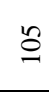 & 농 & 농 \\
\hline & $\begin{array}{c}\text { Lighting } \\
\text { (kWh) }\end{array}$ & $\stackrel{m}{m}$ & กै & $m$ & 느 & $\dot{m}$ & $\bar{m}$ & ఉे & लै \\
\hline & $\begin{array}{l}\text { Cooling } \\
\text { (Electricity) } \\
\text { (kWh) }\end{array}$ & बㄱ & ने & হ & เొ & $\stackrel{\circ}{\circ}$ & $\stackrel{\circ}{\circ}$ & $\stackrel{\infty}{\sim}$ & कี \\
\hline & $\begin{array}{c}\text { Air } \\
\text { Temperature } \\
\left({ }^{\circ} \mathrm{C}\right) \\
\end{array}$ & $\stackrel{0}{\stackrel{0}{N}}$ & $\stackrel{0}{\stackrel{N}{N}}$ & กิ & ৯े & $\begin{array}{l}\infty \\
\dot{m}\end{array}$ & 尺ें & $\begin{array}{l}\text { N } \\
\stackrel{\sim}{N}\end{array}$ & กิ \\
\hline & $\begin{array}{l}\text { Total Energy } \\
\text { Consumption } \\
(\mathrm{kWh})\end{array}$ & $\stackrel{m}{m}$ & సి & $\hat{m}$ & ลิ & $\stackrel{\mathscr{m}}{\sim}$ & m & 哃 & $\vec{m}$ \\
\hline \multirow{2}{*}{ 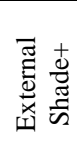 } & $\begin{array}{c}\text { Room } \\
\text { Electricity } \\
(\mathrm{kWh})\end{array}$ & 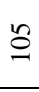 & 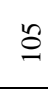 & 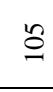 & 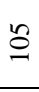 & $\stackrel{2}{\circ}$ & 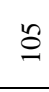 & 농 & $\stackrel{2}{\circ}$ \\
\hline & $\begin{array}{c}\text { Lighting } \\
\text { (kWh) }\end{array}$ & $\hat{~}$ & $\widehat{\curvearrowright}$ & $\stackrel{\infty}{\sim}$ & থ) & $\stackrel{\mathrm{D}}{\sim}$ & $\stackrel{\llcorner}{\sim}$ & $\stackrel{\infty}{\sim}$ & $\widehat{\curvearrowright}$ \\
\hline
\end{tabular}

\begin{tabular}{|c|c|c|c|c|c|c|c|c|}
\hline $\begin{array}{c}\text { Cooling } \\
\text { (Electricity) } \\
\text { (kWh) }\end{array}$ & $\stackrel{\sim}{\stackrel{N}{N}}$ & $\stackrel{\infty}{\stackrel{\infty}{9}}$ & $\underset{\infty}{\stackrel{\infty}{二}}$ & $\stackrel{\text { L }}{6}$ & $\stackrel{\circ}{\circ}$ & $\because$ & & $\stackrel{\text { ¿ }}{ }$ \\
\hline $\begin{array}{c}\text { Air } \\
\text { Temperature } \\
\left({ }^{\circ} \mathrm{C}\right)\end{array}$ & $\stackrel{\Omega}{\curvearrowright}$ & 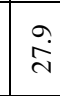 & 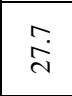 & $\stackrel{\text { Lִ }}{\stackrel{\sim}{N}}$ & 어 & $\underset{\text { }}{\tilde{N}}$ & $\begin{array}{l}\stackrel{10}{\sim} \\
\stackrel{\sim}{N}\end{array}$ & $\stackrel{\infty}{\stackrel{\infty}{~}}$ \\
\hline $\begin{array}{l}\text { Total Energy } \\
\text { Consumption } \\
(\mathrm{kWh})\end{array}$ & $\begin{array}{l}\infty \\
m \\
m\end{array}$ & 隹 & $\underset{\tilde{N}}{\tilde{N}}$ & ి. & 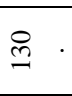 & 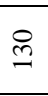 & 品 & $\stackrel{m}{m}$ \\
\hline
\end{tabular}

\section{RESULTS ANALYSIS}

The results indicated that case 2 has the minimum energy consumption all over the year because we used over hang wooden shed plus double glassing, this situation reduced the gaining heat from the surrounding environment that allowed the internal temperature to be lowered compared to other cases as it shown in figures 12,13 and 14 , Also case 2 showed the minimum internal average temperature all over the summer which indicated that the optimum building upgrading case is case 2, while case 5 showed the minimum energy consumption during the winter beside case 2, this is due to the fact that wind capture works as a barrier that prevents cold air from entering into the building during the winter, also wind capture produce air flow that can reduce internal temperature during the summer which will decrease the total energy consumption as it shown in figure 15 .

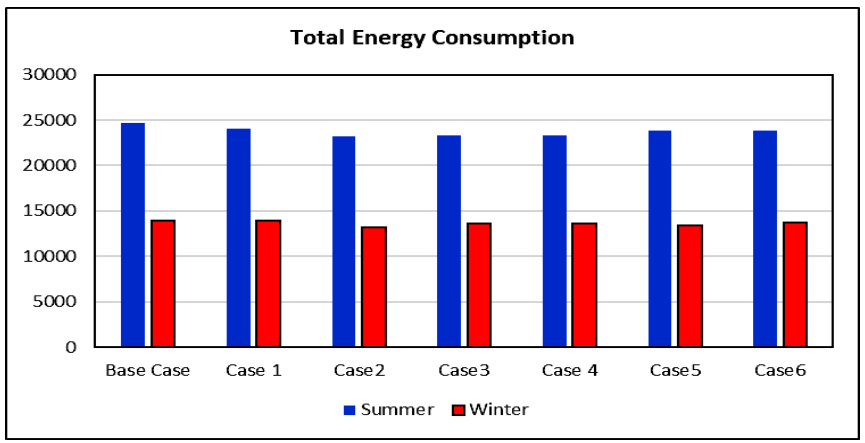

Fig. 12. Total energy consumption for cases all over the year

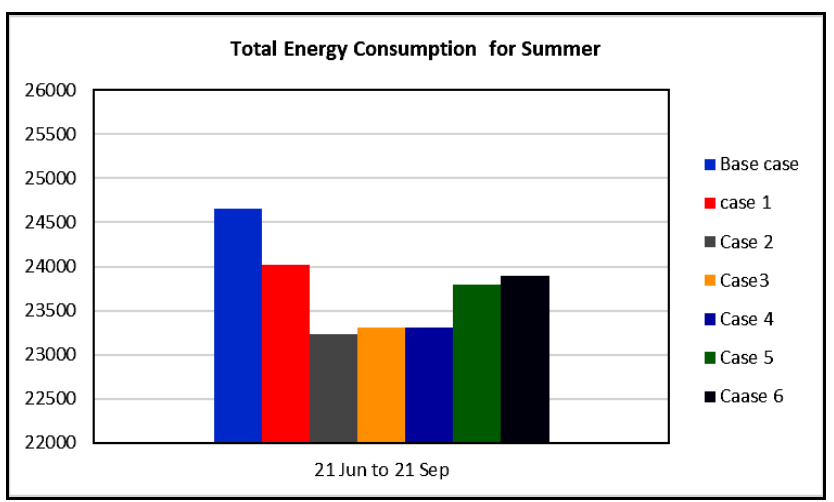

Fig. 13. Total energy consumption for all cases at Summer
Published By:

Blue Eyes Intelligence Engineering and Sciences Publication

(C) Copyright: All rights reserved.

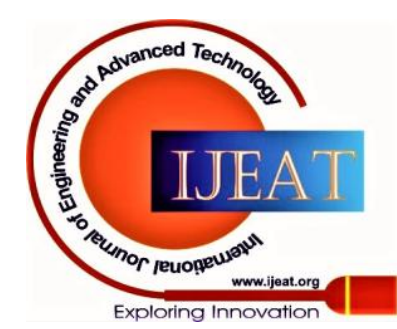




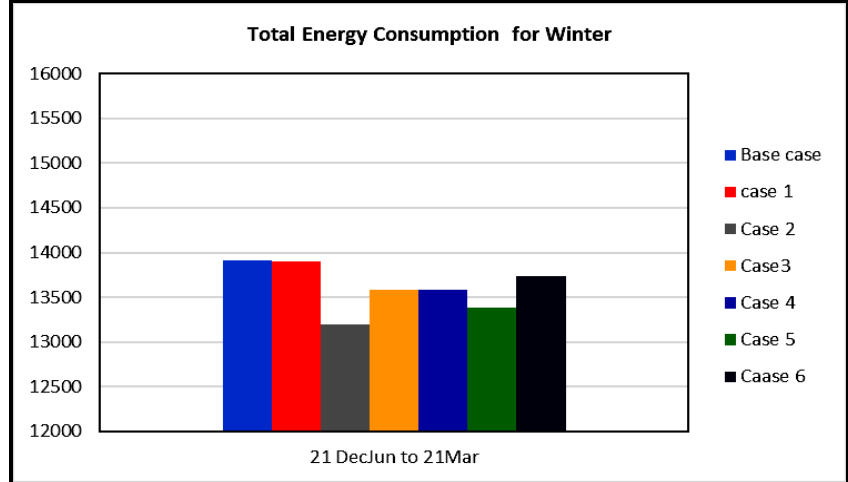

Fig. 14. Total energy consumption for all cases at Winter

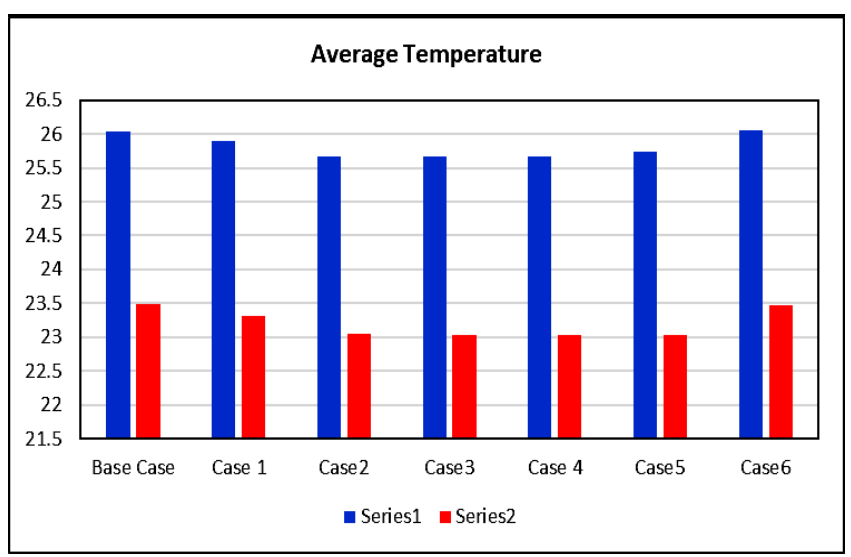

Fig. 15. Average temperature for all cases at Summer

Regarding CFD results for Base case we can see that the rate of change air per hour reached its maximum value at February and at October (2.2 ac/h and 2.1 ac/h respectively ), while during the summer period the ac/h value was an average value ranged from 1.8 to $1.9 \mathrm{ac} / \mathrm{h}$ as it shown in figure 16 , the internal temperature reached maximum value $\left(35.16{ }^{\circ} \mathrm{C}\right.$ ) at august as it shown in figure 17, SCF results for case 2 showed a progress in the rate of air change per hour , the air change range rate for case 2 ranged from 1.83 to $1.93 \mathrm{ac} / \mathrm{h}$ and that due to the fact that the wooden shading device allows more air flow to enter the rooms to decrease the internal temperature as it shown in figure 18. The results for case 5 indicted that the air change rate ranged from 1.82 to $1.92 \mathrm{ac} / \mathrm{h}$ and that due to the fact that wind capture allows more captured air flow to enter the rooms to decrease the internal temperature as it shown in figure 19 , while the internal temperature reached maximum value $\left(36.24{ }^{\circ} \mathrm{C}\right.$ ) at august for case 5 as it shown in figure 20 . All that indicated that the best building upgrading technique is case 2 that used double glassing plus over hang wooden shed. It can be shown from figure 17 that represents air velocity and temperature for base case and case 2 that the air flow advection due to the opening of all windows on south and north frontage, this increased air velocity at south part of the building to reach $4.45 \mathrm{~m} / \mathrm{sec}$ while at the north part the air velocity was vary from $0.54 \mathrm{~m} / \mathrm{sec}$ to $1.91 \mathrm{~m} / \mathrm{sec}$. Also from figure 20 that represents air velocity and temperature for case 5 we can see that the air flow advection increased due to the wind capture with $10 \%$ penetration ratio on south frontage, it allowed air velocity at south part of the building to reach 3.82 $\mathrm{m} / \mathrm{sec}$ while at the north part the air velocity was vary from $0.54 \mathrm{~m} / \mathrm{sec}$ to $1.91 \mathrm{~m} / \mathrm{sec}$.

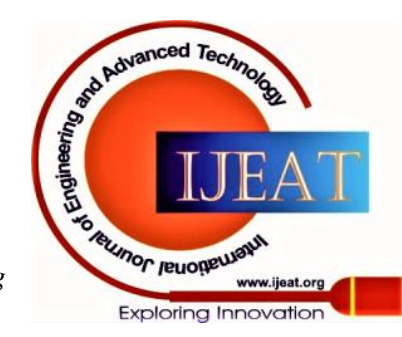




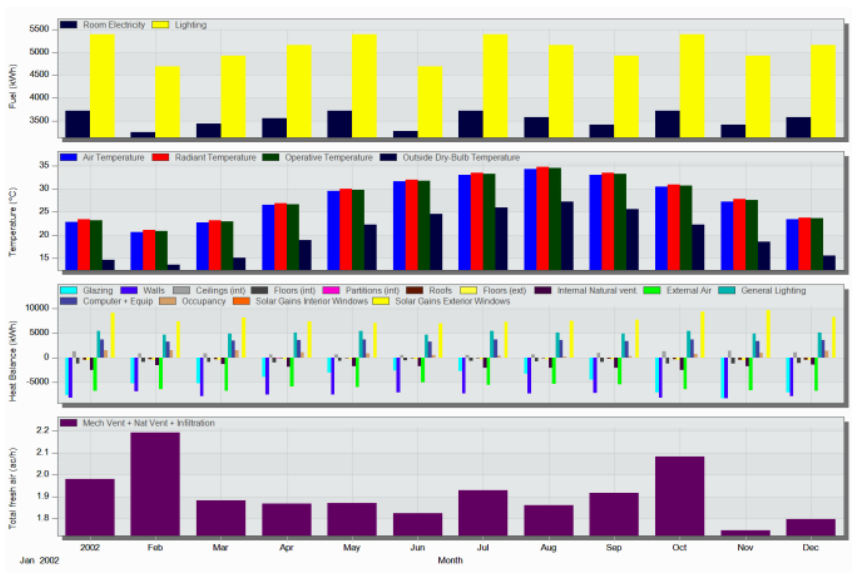

Figure 19 Heat gain, energy consumption and wind speed for case 5 all over the year

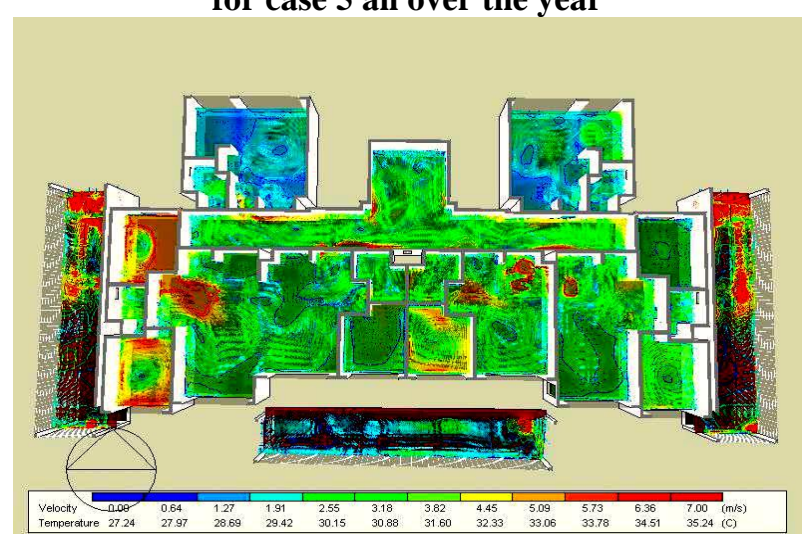

Figure 20 Average wind speed for case 5 at the intermediate floor all over the year

\section{CONCLUSIONS}

1. The paper aims to identify different variables, to establish their difference in an effective way affecting the building performance, for increasing the thermal conditions of coastal nation dwellings in a low-cost way.

2. The study simulation requires the use of the existing building quality that we can build upon it our reliable sources, to assess the impact of existed input building and on the energy, consumption results of simulation as an added value.

3. The local climate contest is the main fundamental for choosing the compatible energy performance of buildings (EPB) that differs upon its energy consumption.

4. Through this simulation, we can adapt any climate change scenarios, that will include temperature raising, to achieve the internal thermal comfort.

5 . The best building upgrading technique is the using of wooden shading device to decrease both energy consumption and the internal temperature to achieve thermal comfort for the residents.

6. Utilizing wind capture as a double skin façade for harvesting the cold air flow to increase its velocity inside the building.

\section{REFERENCES}

1. M. M. Iskander, "Wave climate and coastal structures in the Nile delta coast of Egypt", . Emirates Journal for Engineering Research, 2013.

2. World Bank, "The World Bank participation sourcebook" Washington, D.C, 1996.

3. USAID, "The World Bank participation sourcebook", fact sheets, 2015.
4. A. H. El-Nahry, R. Doluschitz, "Climate change and its impacts on the coastal zone of the Nile Delta, Egypt," , Environmental Earth Sciences, 59(7), 2009, pp. 1497-1506

5. https://en.wikipedia.org/wiki/Thermal_comfort

6. A. Mamdooh,, "Impact of Building Function on Thermal Comfort", American Journal of Engineering and Applied Sciences. 9, 2016, pp. 928-945.

7. https://en.wikipedia.org/wiki/Matrouh_Governorate

8. https://egyptbesttrip.com/marsa-matrouh

9. https://weather-and-climate.com/average-monthly-Rainfall-Temperatur e-Sunshine,marsa-matruh-matruh-eg,Egypt

10. https://en.wikipedia.org/wiki/Mersa_Matruh\#Climate

11. M. A. Kamal, "An overview of passive cooling techniques in buildings: design concepts and architectural interventions", Civil Engineering \& Architecture, 55(1), 2012, pp. 84-97.

12. W. Batty, H. Al-Hinai, S. Probert, "Natural-cooling techniques for residential buildings in hot climates", Applied Energy, 39(4), 1991, pp. 301-337.

13. R.. Kumar, S. N. Garg, S. C. Kaushik, "Performance evaluation of multi-passive solar applications of a non-air-conditioned building International", Journal of Environmental Technology and Management, 5(1),, 2005, pp. 15-64.

14. S. Rajendran, D. Jena, "Variable speed wind turbine for maximum power capture using adaptive fuzzy integral sliding mode control", Journal of Modern Power Systems and Clean Energy, 2(2),, 2014, pp. 114-125.

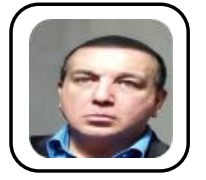

\section{AUTHORS PROFILE}

Tamer Elgohary is an Associate Professor at Civil Department, Faculty of Engineering Heliopolis University, Cairo, Egypt. He is also the head of Civil department. He is doing his professional work as a lecturer and also a consultant. His research interest includes water engineering, harbour engineering, environmental and irrigation.

Nisreen Abdeen is an assistant professor at Architecture Department, Faculty of Engineering Heliopolis University, Cairo, Egypt. She is doing her professional work as a lecturer and also as a consultant. Her research interest includes urban design, city planning, environmental and green design

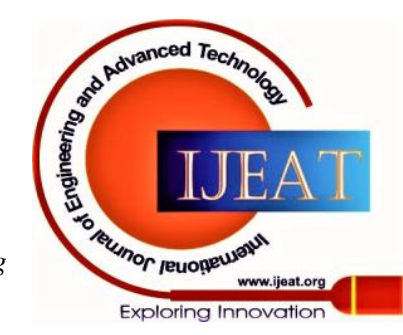

